\title{
Tapasztalataink az alsó végtagi perifériás artériás érbetegség szüréséről az Észak-Magyarország régióban
}

\author{
Tóth-Vajna Zsombor dr. ${ }^{1}$ - Tóth-Vajna Gergely dr. ${ }^{2}$ - Gombos Zsuzsanna dr. ${ }^{3}$ \\ Szilágyi Brigitta ${ }^{4}$ - Járai Zoltán dr., ${ }^{5,6}$ Sótonyi Péter dr. ${ }^{1}$ \\ 'Semmelweis Egyetem, Általános Orvostudományi Kar, Városmajori Szív- és Érgyógyászati Klinika, \\ Érsebészeti Tanszék, Budapest \\ ${ }^{2}$ Semmelweis Egyetem, Magatartástudományi Intézet, Budapest \\ ${ }^{3}$ Borsod-Abaúj-Zemplén Megyei Központi Kórház és Egyetemi Oktatókórház, \\ Központi Aneszteziológiai és Intenzív Terápiás Osztály, Miskolc \\ ${ }^{4}$ Budapesti Múszaki és Gazdaságtudományi Egyetem, Geometriai Tanszék, Matematikai Intézet, Budapest \\ ${ }^{5}$ Szent Imre Egyetemi Oktatókórház, Általános Kardiológiai Profil, Budapest \\ ${ }^{6}$ Semmelweis Egyetem, Általános Orvostudományi Kar, Városmajori Szív- és Érgyógyászati Klinika, \\ Érsebészeti Tanszék, Angiológiai Tanszéki Csoport, Budapest
}

\begin{abstract}
Bevezetés: A boka-kar index (BKI) mérése az első választandó szűrőmódszer az alsó végtagi perifériás artériás érbetegség (LEAD) diagnosztikájában. A LEAD tekintetében veszélyeztetett populációban végzett szűrés célja a major végtagi események, így az amputáció kockázatának csökkentése. A nyugalmi BKI-érték ugyanakkor könnyen adhat álnegatív eredményt.

Célkitüzés: Kutatásunk célja egy, a családorvosi praxisban könnyen megvalósítható, gyors és költséghatékony szürőmódszer tesztelése mellett azon betegek azonosítása volt, akiknél a családorvos eszközeivel nem kaphatunk definitív diagnózist (negatív BKI mellett tünetes, illetve nem komprimálható artériás csoport).

Módszer: Az Észak-Magyarország régióban 680 beteg szúrését végeztük el. Edinburgh-kérdőívet használtunk, rögzítettük a saját és a családi anamnézist, a rizikófaktorokat, a jelenlegi panaszokat és a gyógyszerelést. Fizikális vizsgálatot és BKI-mérést végeztünk.

Eredmények: A betegek 34\%-a jelzett alsó végtagi claudicatiót, 23\%-nak volt abnormális BKI-értéke, 14\% jelzett normális BKI-érték mellett dysbasiás panaszokat. 12\% került a nem komprimálható artériás csoportba. A BKI alapján negatív, de tünetes csoport rizikófaktor-profilja jelentős hasonlóságot mutatott a biztosan LEAD-pozitív és a nem komprimálható artériás csoport rizikófaktor-profiljával.

Következtetés: A LEAD valós előfordulása magasabb lehet, mint a csak a BKI alapján történő szürés eredménye. A populáció közel negyede került a BKI alapján a negatív, de tünetes és a nem komprimálható artériás csoportba. Ezen csoport betegei a családorvos részéról különös odafigyelést igényelnek. A normális BKI-érték ellenére - ha felmerül a LEAD klinikai gyanúja - további vizsgálatok szükségesek. A LEAD szúrése többirányú megközelítést igényel. Orv Hetil. 2020; 161(33): 1381-1389.
\end{abstract}

Kulcsszavak: alsó végtagi verőérbetegség, boka-kar index, diabetes, szűrés

\section{A summary of data of screening of the lower limb peripheral arterial diseases in the region of Northern Hungary}

Introduction: The screening tool for diagnosing lower extremity arterial disease (LEAD) is the assessment of the ankle-brachial index (ABI). In patients at risk for LEAD, the purpose of screening is to avoid major adverse limb events, such as amputation. However, resting ABI can easily produce a false negative result.

Aim: In light of this, our goal was to test the usefulness of an easily performed, fast and cost-effective screening method and to determine the proportion of subjects without definitive diagnoses among patients screened in general practice (with special attention to groups having negative ABI with symptoms and patients with non-compressible arteries). 
Method: 680 patients were screened from the region of Northern Hungary. We used the Edinburgh Questionnaire, recorded medical histories, major risk factors, current complaints, and medication. Physical examinations were performed, including ABI testing.

Results: $34 \%$ complained about lower extremity claudication; $23 \%$ had abnormal ABI values; $14 \%$ of the patients within the normal ABI range had complaints of dysbasia; $12 \%$ were in the non-compressible artery group. The ABInegative symptomatic group's risk factor profile showed a close similarity to the clear LEAD-positive and non-compressible artery groups.

Conclusion: The percentage of LEAD could be higher than the number of patients diagnosed by ABI screening. Nearly a quarter of the population fell into the non-compressible artery and ABI-negative symptomatic groups. When screening purposely for LEAD, these patients deserve special attention due to the insufficient selectivity and sensitivity of measurements. If there is a high clinical suspicion of LEAD in spite of normal ABI values, further assessment may be considered.

Keywords: lower extremity arterial disease, ankle-brachial index, diabetes, screening method

Tóth-Vajna Zs, Tóth-Vajna G, Gombos Zs, Szilágyi B, Járai Z, Sótonyi P. [A summary of data of screening of the lower limb peripheral arterial diseases in the region of Northern Hungary]. Orv Hetil. 2020; 161(33): 1381-1389.

(Beérkezett: 2020. február 12.; elfogadva: 2020. március 20.)

\section{Rövidítések}

$\mathrm{BKI}=$ boka-kar index; ECQ = $($ Edinburgh Claudication Questionnaire) Edinburgh claudicatiós kérdőív; ÉRV Program = Ereink Védelmében Program; $\mathrm{HbA}_{\mathrm{lc}}=$ hemoglobin- $\mathrm{A}_{\mathrm{lc}} ; \mathrm{HDL}$ = (high-density lipoprotein) magas sürüségü lipoprotein; LDL = (low-density lipoprotein) alacsony sűrüségű lipoprotein; LEAD $=($ lower extremity arterial disease $)$ alsó végtagi verőérbetegség; $\mathrm{MI}=$ myocardialis infarctus; $\mathrm{TBI}=$ (toe-brachial in dex) öregujj-kar index; $\mathrm{UH}=$ ultrahang

Európában a cardiovascularis betegségek a vezető halálokok, hatalmas szociális és gazdasági terhet jelentve a társadalom számára [1]. Az alsó végtagi artériás betegség (lower extremity arterial disease - LEAD) többnyire az általános atherosclerosis része, ritkán fordul elő izolált betegségként. Magyarországon a családorvosi praxisban a gyakori, de csak részben felismert betegségek közé tartozik. A nem traumás okból végzett amputációk hátterében döntően ez a betegségcsoport áll [2].

Magyarországon a vizhub.healthdata.org 2016-os adatai alapján a LEAD az összhalálozás $0,43 \%$-áért volt felelős [3].

A betegség korai felismerése kiemelt jelentőségű, mert az érbetegek kockázata egy jövőbeli cardiovascularis vagy cerebrovascularis esemény elszenvedésére 2-4-szer nagyobb, mint az érbetegségben nem szenvedőké [1, 4-6]. Éppen ezért a betegség korai felismerése és kezelése jelentősen segíthet a rizikó és a halálozás csökkentésében [7].

A LEAD gyakori megbetegedésnek számít. Előfordulása az 55 év feletti korosztályban exponenciálisan nő, 65 éves kor felett prevalenciája elérheti a $20 \%$-ot is [ 1 , 8-12]. Fontos körülmény, hogy a LEAD-ban szenvedő páciensek többsége aszimptomatikus, így célzott szưrés hiányában a betegség felismeretlen marad $[1,7]$.
Az ezen a területen végzett eddigi legjelentősebb magyar epidemiológiai vizsgálat, az ÉRV Program (Ereink Védelmében Program) során a LEAD gyakoriságát hypertoniás betegek szürése kapcsán 14,4\%-ra mérték. A 21892 beteg (átlagéletkor: 61,45 év) vizsgálata szakorvosi körülmények között történt, hypertonia-szakellátóhelyeken [13].

A LEAD rizikófaktorai megegyeznek a többi atheroscleroticus betegség rizikófaktoraival $[1,7]$. A legfontosabbak a dohányzás, a diabetes mellitus, a dyslipidaemia, a hypertonia, az életkor [7]. A magyar lakosság körében a magasvérnyomás-betegség a leggyakoribb rizikófaktorok közé tartozik.

Magyarországon a boka-kar index (BKI) mérése a kötelező családorvosi rutinvizsgálatok részét képezi, tapasztalataink szerint mégis viszonylag ritkán kerül kivitelezésre. Ez a megállapítás különösen jelentős annak tükrében, hogy a hazai amputációk száma többszöröse a nemzetközi irodalomban közölteknek [2].

Vizsgálataink célja a LEAD előfordulásának és súlyosságának felmérése mellett egy egyszerű, kevés eszközzel, költséghatékonyan és kevés időráfordítással a családorvos számára is könnyen kivitelezhető komplex szűrőmetódus kidolgozása volt, amely hatékonyan segíthet az érintett vagy veszélyeztetett betegek minél egyszerúbb kiszűrésében, korai felismerésében. A LEAD célzott szűrése mellett fontos a társuló cardio- és cerebrovascularis betegségek korai felismerése is. Kutatásunkban célul tűztük ki, hogy felmérjük a LEAD gyakoriságát a hazai családorvosi ellátásban megforduló betegek között, és megbecsüljük a rendelkezésünkre álló szűrőmódszerek hatékonyságát, a vizsgált népességben előforduló rizikófaktorok tükrében. Az egyik ilyen csoport, amelynek tagjai a nyugalmi BKI-mérés alkalmával a normális tartományba eső vagy átmeneti értékkel, az Edinburgh-kérdőív alapján viszont claudicatiós panaszokkal rendelkeztek 
1. táblázat | Az Észak-Magyarország régióra vonatkozó KSH-adatok

\begin{tabular}{lllrrr}
\hline A település neve & Jogállás & Régió & Népesség (fó) & $\begin{array}{c}\text { A leszúrt } \\
\text { betegek száma }\end{array}$ & $\begin{array}{c}\text { A leszúrt } \\
\text { betegek } \\
\text { százalékos aránya }\end{array}$ \\
\hline Alsózsolca & Város & Észak-Magyarország & 5683 & 37 & 0,65 \\
\hline Bogács & Község & Észak-Magyarország & 1960 & 31 & 1,58 \\
\hline Edelény & Város & Észak-Magyarország & 9739 & 20 & 0,21 \\
\hline Felsózsolca & Város & Észak-Magyarország & 6521 & 50 & 0,77 \\
\hline Kazincbarcika & Város & Észak-Magyarország & 27487 & 25 & 0,09 \\
\hline Mezöcsát & Város & Észak-Magyarország & 5882 & 23 & 0,39 \\
\hline Mezőkeresztes & Város & Észak-Magyarország & 3818 & 30 & 0,79 \\
\hline Miskolc & Megyeszékhely, megyei jogú város & Észak-Magyarország & 159554 & 121 & 0,08 \\
\hline Ónod & Község & Észak-Magyarország & 2340 & 34 & 1,45 \\
\hline Sajószentpéter & Város & Észak-Magyarország & 11679 & 48 & 0,41 \\
\hline Tállya & Község & Észak-Magyarország & 1892 & 107 & 5,66 \\
\hline Tiszalúc & Nagyközség & Észak-Magyarország & 5064 & 114 & 2,25 \\
\hline Tiszaújváros & Város & Észak-Magyarország & 16168 & 40 & 0,25 \\
\hline
\end{tabular}

Forrás: Magyarország közigazgatási helynévkönyve, 2015. január 1. (magyar és angol nyelven). Központi Statisztikai Hivatal, 2015. szeptember 3.

KSH = Központi Statisztikai Hivatal

(BKI-negatín, de tünetes csoport), a másik pedig azok a betegek, akiknél a nagyartériáik merevsége miatt hamisan magas BKI-értéket kaptunk (nem komprimálható artériás csoport). Az utóbbi két csoportot nevezzük a diagnosztikai nehézségek miatt a továbbiakban „ködzónának”.

\section{Betegek és módszer}

Vizsgálatainkat 2015 novemberétôl 2017 áprilisáig végeztük az Észak-Magyarország régió 13 településének 680 betege (261 férfi, 419 nő) bevonásával (1. táblá$z a t)$.

A szưrést a vizsgálat előtt 1 hónappal hirdettük meg a családorvosi rendelókben, a vizsgálatok is itt történtek. A szürésre 50 év feletti férfiakat és nőket vártunk, akiknél legalább egy major vascularis rizikófaktor állt fenn (dohányzás vagy cukorbetegség vagy magas koleszterinszint vagy hypertonia), illetve akiknél a saját, illetve a családi anamnézisben korábban előfordult bármilyen cardio-, illetve cerebrovascularis történés.

A megjelent betegektől első lépésként kikérdeztük az Edinburgh claudicatiós kérdöívet (ECQ), amely a claudicatio intermittens szürésének validált és elterjedt módszere, szenzitivitása $80-90 \%$, specificitása pedig $95 \%$ feletti [14]. A kérdőív nemcsak a panaszok jellegére, hanem az esetleges artériás szúkület mértékére és a szükület szintjére (helyére) is iránymutató lehet.

Felvettük a betegek saját anamnézisét, a családi anamnézisben előforduló cardiovascularis történéseket, az aktuális gyógyszerelést, valamint a fó rizikófaktorokkal (dohányzás, cukorbetegség, hypertonia, hyperlipidaemia) kapcsolatban részletesebb adatokat rögzítettünk arra vonatkozóan, hogy mióta tud a betegségéről, illetve dohányosok esetében rákérdeztünk a naponta elszívott cigaretták mennyiségére (1. ábra).

A különböző értékek számításához szükséges méréseket végeztünk (testmagasság, testsúly, derékkörfogatmeghatározás). Tesztcsíkkal vércukor- és koleszterinszint-mérést végeztünk, s a diabeteses, illetve a helyszínen a normálértéknél magasabb eredményt mutató betegek esetében mintát vettünk $\mathrm{HbA}_{1 c}$-vizsgálathoz, amit központi laboratóriumban értékeltettünk ki. 5 perces pihentetés után mind a négy végtag szisztolés vérnyomását megmértük $8 \mathrm{MHz}$-es folyamatos hullámú DopplerUH-készülékkel (multiDOPPY; Medi-CAD Kft., Miskolc) az érvényben lévő ajánlásoknak megfelelően [1], az eredményeket pedig a BKI számításához használtuk fel.

Azokkal a betegekkel, akik az Edinburgh-kérdőív alapján claudicatiós panaszokkal rendelkeztek, járástesztet végeztettünk. Egy előre kimért pályán kellett normális sebességgel sétálniuk. Ezt több adat rögzítéséhez használtuk. Regisztráltuk, hogy a fájdalom 200 méter alatt vagy e felett jelentkezik: ezt a Fontaine-féle stádiumbesoroláshoz használtuk fel (2. táblázat). A betegeket maximum 6 percig sétáltattuk ( 6 perces járástávolság felmérése). Meghatároztuk a fájdalommentes járástávolságot (azt a távolságot, amelynél az alsó végtagi fájdalom először jelentkezett), valamint a maximális járástávolságot (amelynél a fájdalom végképp megállásra késztette óket). 


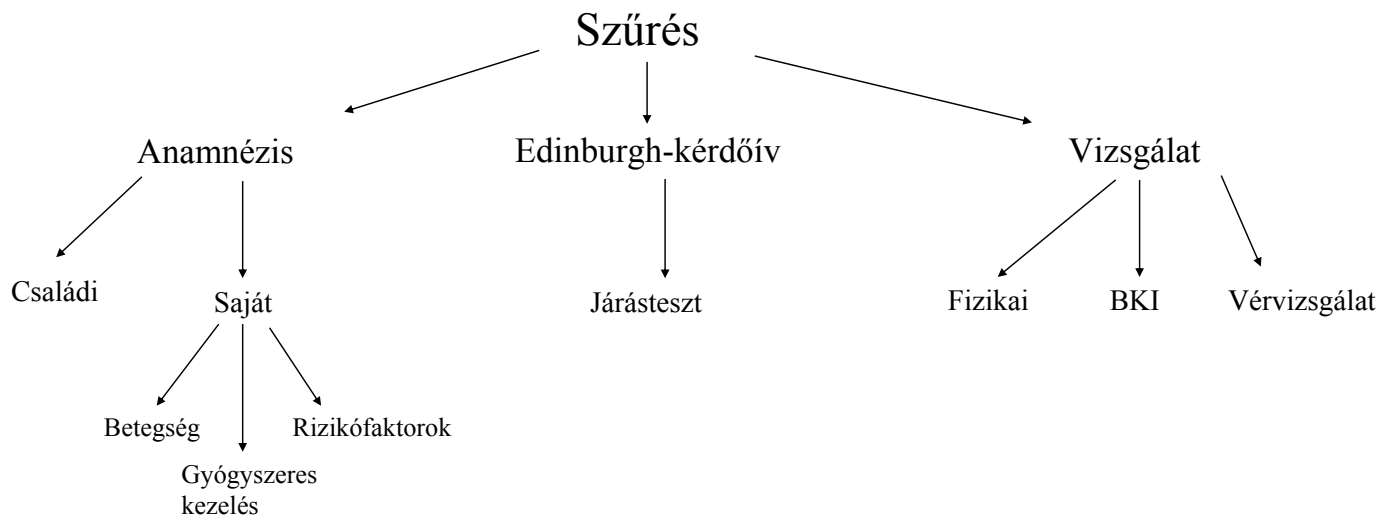

1. ábra

$\mid \begin{aligned} & \text { A cardiovascularis szürés módszertana és elemei } \\ & \text { BKI = boka-kar index }\end{aligned}$

2. táblázat |A Fontaine-féle stádiumbesorolás

\begin{tabular}{lccccc}
\hline Csoportok & $\begin{array}{c}\text { Fontaine } \\
\text { I. }\end{array}$ & $\begin{array}{c}\text { Fontaine } \\
\text { IIa }\end{array}$ & $\begin{array}{c}\text { Fontaine } \\
\text { IIb }\end{array}$ & $\begin{array}{c}\text { Fontaine } \\
\text { III. }\end{array}$ & $\begin{array}{c}\text { Fontaine } \\
\text { IV. }\end{array}$ \\
\hline $\begin{array}{l}\text { Biztosan } \\
\text { LEAD-pozitív }\end{array}$ & 44 & 39 & 75 & 1 & 3 \\
$\begin{array}{l}\text { BKI-negatív, } \\
\text { tünetes }\end{array}$ & 0 & 67 & 24 & 2 & 2 \\
$\begin{array}{l}\text { Nem komprimál- } \\
\text { ható artéria }\end{array}$ & 1 & 10 & 10 & 0 & 1 \\
\hline
\end{tabular}

$\mathrm{BKI}=$ boka-kar index; $\mathrm{LEAD}=$ alsó végtagi verőérbetegség

A nyugalmi BKI és az Edinburgh-kérdőív alapján a betegeket 4 föcsoportba osztottuk (3. táblázat).

Akik a nyugalmi BKI-mérés alkalmával a normális (negatív) tartományba estek, valamint semmilyen tünetét nem mutatták fennálló érszúkületnek, azok a betegek lettek a biztosan LEAD-negatív csoport. Azok a betegek, akiknél a nyugalmi BKI-mérés a normáltartományban volt, de az Edinburgh-kérdöív alapján a claudicatio

3. táblázat $\mid$ A betegek csoportosítása a nyugalmi boka-kar index és az Edinburgh-kérdőív alapján

\begin{tabular}{lcc|cc}
\hline & \multicolumn{2}{c|}{ Fényzóna } & \multicolumn{2}{c}{ Ködzóna } \\
\hline Csoportok & $\begin{array}{c}\text { Biztosan } \\
\text { LEAD- } \\
\text { negatív }\end{array}$ & $\begin{array}{c}\text { Biztosan } \\
\text { LEAD- } \\
\text { pozitív }\end{array}$ & $\begin{array}{c}\text { BKI-negatív, } \\
\text { de tünetes }\end{array}$ & $\begin{array}{c}\text { Nem } \\
\text { komprimál- } \\
\text { ható artéria }\end{array}$ \\
\hline BKI & $0,9-1,4$ & $<0,9$ & $0,9-1,4$ & $>1,4$ \\
\hline Tünetek & Negatív & $\begin{array}{c}\text { Negatív } \\
\text { vagy pozitív }\end{array}$ & Pozitív & $\begin{array}{c}\text { Negatív } \\
\text { vagy pozitív }\end{array}$ \\
\hline $\mathrm{n}(\%)$ & $343(50 \%)$ & $162(23 \%)$ & $95(14 \%)$ & $80(12 \%)$ \\
\hline Férfiak $(\%)$ & $108(31 \%)$ & $91(56 \%)$ & $36(38 \%)$ & $26(32 \%)$ \\
\hline Nők $(\%)$ & $235(69 \%)$ & $71(44 \%)$ & $59(62 \%)$ & $54(68 \%)$ \\
\hline $\begin{array}{l}\text { Átlagéletkor } \\
( \pm \text { SD })\end{array}$ & $\begin{array}{c}64,1 \\
( \pm 7,6)\end{array}$ & $\begin{array}{c}66,6 \\
( \pm 7,8)\end{array}$ & $\begin{array}{c}66,3 \\
( \pm 7,7)\end{array}$ & $\begin{array}{c}66,8 \\
( \pm 8,9)\end{array}$ \\
\hline
\end{tabular}

$\mathrm{BKI}$ = boka-kar index; $\mathrm{LEAD}$ = alsó végtagi verőérbetegség; $\mathrm{SD}=$ a minta szórása intermittens tüneteit mutatták, a BKI alapján negatív, de tünetes csoportba kerültek.

A biztosan LEAD-pozitív csoportba azok a betegek kerültek, akik a nyugalmi BKI-mérés alkalmával a pozitív tartományban voltak, így náluk nagy biztossággal kimondható az artériás szúkület megléte, függetlenül attól, hogy rendelkeztek-e a claudicatio intermittens tüneteivel, vagy éppen aszimptomatikusak voltak.

A nagyartériák merevségét több kóroki folyamat okozhatja, ami ún. nem komprimálható nagyartériákhoz vezet. Ezekben az esetekben a BKI-mérések alkalmával hamisan magas, 1,4 feletti értékeket kaptunk. Ezt a betegcsoportot emiatt a nem komprimálható artériás csoportnak neveztük el, utalva az itt felmerülő diagnosztikai nehézségekre.

A biztosan LEAD-pozitív és a biztosan LEAD-negatív csoport betegeit neveztük el „fényzónának”, mert az általunk használt szűrőmetódus segítségével ezek a páciensek nagy biztonsággal felismerhetők a családorvosok számára. Ezzel szemben a BKI-negatív, de tünetes és a nem komprimálható artériás csoportba tartozó betegeket „ködzónának” hívtuk, utalva az ezen csoportokban felmerülő diagnosztikai nehézségekre.

\section{Eredmények}

Eredményeinket a 4. és 5. táblázatban foglaltuk össze.

\section{A teljes populáció adatai}

A populáció átlagéletkora $65,3( \pm 7,9)$ év volt. A leggyakoribb rizikófaktor a hypertonia volt 79\%-kal. A leggyakrabban szedett gyógyszerek is ennek megfelelően a vérnyomáscsökkentők voltak.

\section{Biztosan LEAD-negatí csoport}

Ebbe a csoportba a vizsgált populáció 50\%-a került. Az életkori átlag ebben a csoportban volt a legalacsonyabb, $64,1( \pm 7,6)$ év. A leggyakoribb rizikófaktor a hypertonia 
4. táblázat | Életkori eloszlás

\begin{tabular}{lcc|cc}
\hline & \multicolumn{2}{c|}{ Fényzóna } & Ködzóna populáció \\
\hline Csoportok & $\begin{array}{c}\text { Biztosan } \\
\text { LEAD-negatív }\end{array}$ & $\begin{array}{c}\text { Biztosan } \\
\text { LEAD-pozitív }\end{array}$ & $\begin{array}{c}\text { BKI-negatív, } \\
\text { de tünetes }\end{array}$ & $\begin{array}{c}\text { Nem komprimálható } \\
\text { artéria }\end{array}$ \\
\hline $\begin{array}{l}\text { Életkori átlag (összes) } \\
\pm \text { szórás }\end{array}$ & $64,1( \pm 7,6)$ & $66,6( \pm 7,8)$ & $66,3( \pm 7,7)$ & $66,8( \pm 8,9)$ \\
\hline $\begin{array}{l}\text { Életkori átlag (férfiak) } \\
\pm \text { szórás }\end{array}$ & $63,7( \pm 6,8)$ & $66,2( \pm 7,0)$ & $66,0( \pm 7,31)$ & $68,9( \pm 7,5)$ \\
\hline $\begin{array}{l}\text { Életkori átlag (nók) } \\
\pm \text { szórás }\end{array}$ & $64,3( \pm 7,9)$ & $67,2( \pm 8,7)$ & $66,5( \pm 7,9)$ & $65,7( \pm 9,4)$ \\
\hline
\end{tabular}

$\mathrm{BKI}=$ boka-kar index; LEAD = alsó végtagi verőérbetegség

5. táblázat |A vizsgált régióban élők egészségével kapcsolatos rizikófaktorok

\begin{tabular}{|c|c|c|c|c|c|c|c|c|c|c|}
\hline \multirow{3}{*}{ Csoportok } & \multicolumn{2}{|c|}{ Fényzóna } & \multicolumn{2}{|c|}{ Ködzóna } & \multirow{2}{*}{\multicolumn{5}{|c|}{ p-értékek }} & \multirow{2}{*}{$\begin{array}{c}\text { Teljes } \\
\text { populáció } \\
(\mathrm{n}=680)\end{array}$} \\
\hline & $\begin{array}{c}\text { Biztosan } \\
\text { LEAD- } \\
\text { negatív } \\
(\mathrm{n}=343) \text { A }\end{array}$ & $\begin{array}{c}\text { Biztosan } \\
\text { LEAD- } \\
\text { pozitív } \\
(\mathrm{n}=162) \mathrm{B}\end{array}$ & $\begin{array}{l}\text { BKI-negatív, } \\
\text { de tünetes } \\
(\mathrm{n}=95) \\
\mathrm{C}\end{array}$ & $\begin{array}{l}\text { Nem } \\
\text { komprimál- } \\
\text { ható artéria } \\
(\mathrm{n}=80) \mathrm{D}\end{array}$ & & & & & & \\
\hline & $\begin{array}{c}\text { Elófordulás } \\
\text { a csoportban } \\
(\mathrm{n}, \%)\end{array}$ & $\begin{array}{l}\text { Előfordulás } \\
\text { a csoport- } \\
\text { ban }(n, \%)\end{array}$ & $\begin{array}{l}\text { Elöfordulás } \\
\text { a csoport- } \\
\text { ban }(n, \%)\end{array}$ & $\begin{array}{l}\text { Elöfordulás } \\
\text { a csoport- } \\
\text { ban }(n, \%)\end{array}$ & A vs. B & A vs. C & A vs. D & B vs. C & C vs. D & $\begin{array}{c}\text { Előfordulás } \\
\text { az összes } \\
\text { vizsgált } \\
\text { esetben }\end{array}$ \\
\hline Aktív dohányzó & $56(16 \%)$ & $73(45 \%)$ & $26(27 \%)$ & $13(16 \%)$ & $<0,0001$ & 0,0633 & $>0,999$ & 0,0616 & 0,211 & $168(25 \%)$ \\
\hline $\begin{array}{l}\text { Korábban dohány- } \\
\text { zott }\end{array}$ & $80(23 \%)$ & $46(28 \%)$ & $21(22 \%)$ & $21(26 \%)$ & 0,3427 & 0,8939 & 0,6476 & 0,4747 & 0,7308 & $168(25 \%)$ \\
\hline Hypertonia & $249(73 \%)$ & $144(89 \%)$ & $78(82 \%)$ & $64(80 \%)$ & 0,1565 & 0,4859 & 0,6388 & 0,7034 & $>0,9999$ & $535(79 \%)$ \\
\hline Cukorbetegség & $100(29 \%)$ & $55(34 \%)$ & $31(33 \%)$ & $32(40 \%)$ & 0,4356 & 0,6328 & 0,2138 & 0,898 & 0,5566 & $218(32 \%)$ \\
\hline Hyperlipidaemia & $162(47 \%)$ & $112(69 \%)$ & $58(61 \%)$ & $33(41 \%)$ & 0,015 & 0,2035 & 0,5776 & 0,6064 & 0,1519 & $365(54 \%)$ \\
\hline Korábbi stroke & $17(5 \%)$ & $15(9 \%)$ & $13(14 \%)$ & $2(3 \%)$ & 0,119 & 0,0119 & 0,5477 & 0,4122 & 0,0153 & $47(7 \%)$ \\
\hline Korábbi MI & $15(4 \%)$ & $17(10 \%)$ & $22(23 \%)$ & $4(5 \%)$ & 0,0195 & $<0,0001$ & 0,7681 & 0,0232 & 0,0048 & $58(9 \%)$ \\
\hline $\begin{array}{l}\text { Korábbi PAD- } \\
\text { diagnózis }\end{array}$ & $13(4 \%)$ & $37(23 \%)$ & $32(34 \%)$ & $12(15 \%)$ & 0,0001 & $<0,0001$ & 0,0014 & 0,1662 & 0,0277 & $94(14 \%)$ \\
\hline
\end{tabular}

\begin{tabular}{|c|c|c|c|c|c|c|c|c|c|c|}
\hline Elhízás & $268(78 \%)$ & $110(68 \%)$ & $69(73 \%)$ & $64(80 \%)$ & 0,3768 & 0,723 & 0,9258 & 0,7636 & 0,7298 & $511(75 \%)$ \\
\hline Alkoholizmus & $8(2 \%)$ & $3(2 \%)$ & $0(0 \%)$ & $4(5 \%)$ & $>0,9999$ & 0,2119 & 0,2582 & 0,3017 & 0,0467 & $15(2 \%)$ \\
\hline $\begin{array}{l}\text { Claudicatio pozitív } \\
\text { (összes) }\end{array}$ & 0 & $118(73 \%)$ & $95(100 \%)$ & $21(26 \%)$ & $<0,0001$ & $<0,0001$ & $<0,0001$ & 0,1089 & $<0,0001$ & $233(34 \%)$ \\
\hline $\begin{array}{l}\text { Claudicatio pozitív } \\
\text { (férfiak) }\end{array}$ & 0 & $63(39 \%)$ & $37(39 \%)$ & $7(9 \%)$ & $<0,0001$ & $<0,0001$ & $<0,0001$ & $>0,9999$ & $<0,0005$ & $106(16 \%)$ \\
\hline $\begin{array}{l}\text { Claudicatio pozitív } \\
\text { (nők) }\end{array}$ & 0 & $55(34 \%)$ & $58(61 \%)$ & $14(17 \%)$ & $<0,0001$ & $<0,0001$ & $<0,0001$ & 0,0117 & $<0,0001$ & $127(19 \%)$ \\
\hline \multicolumn{11}{|l|}{ Gyógyszerelés } \\
\hline Vérnyomáscsökkentő & $226(66 \%)$ & $130(80 \%)$ & $78(82 \%)$ & $57(71 \%)$ & 0,1885 & 0,2173 & 0,6985 & 0,9234 & 0,5655 & $491(72 \%)$ \\
\hline Lipidcsökkentő & $83(24 \%)$ & $54(33 \%)$ & $38(40 \%)$ & $13(16 \%)$ & 0,126 & 0,0301 & 0,2409 & 0,5318 & 0,01 & $188(28 \%)$ \\
\hline Antidiabetikus & $71(21 \%)$ & $42(26 \%)$ & $26(27 \%)$ & $19(24 \%)$ & 0,3198 & 0,2847 & 0,6594 & 0,8882 & 0,7383 & $158(23 \%)$ \\
\hline Thrombocytagátlók & $70(20 \%)$ & $63(39 \%)$ & $41(43 \%)$ & $22(27 \%)$ & 0,0015 & 0,0013 & 0,3119 & 0,7193 & 0,1813 & $196(29 \%)$ \\
\hline PAD-specifikus & $7(2 \%)$ & $39(24 \%)$ & $32(34 \%)$ & $5(6 \%)$ & $<0,0001$ & $<0,0001$ & 0,0639 & 0,2189 & $<0,0005$ & $83(12 \%)$ \\
\hline Vízhajtó & $17(5 \%)$ & $5(3 \%)$ & $13(14 \%)$ & $4(5 \%)$ & 0,484 & 0,0119 & $>0,9999$ & 0,0048 & 0,1226 & $39(6 \%)$ \\
\hline
\end{tabular}

$\mathrm{BKI}$ = boka-kar index; $\mathrm{LEAD}$ = alsó végtagi verőérbetegség; $\mathrm{MI}=$ myocardialis infarctus 
volt (73\%). Az elhízottak száma ebben a csoportban volt a második legmagasabb (78\%). A leggyakoribb gyógyszerek a vérnyomáscsökkentők voltak (66\%).

\section{Biztosan LEAD-pozitín csoport}

A nyugalmi BKI-értékek alapján a vizsgált populáció 23\%-a kategorizálható a biztosan érszúküuletben szenvedők csoportjába. Ebből 56\% volt a férfiak aránya. Az átlagéletkor 66,6 ( $\pm 7,8)$ év volt. A leggyakoribb rizikófaktor itt is a hypertonia volt $(89 \%)$, amely az összes csoport közül itt fordult elő a legmagasabb arányban. Ebben a csoportban volt a legmagasabb az aktív (45\%) és a korábban dohányzók (28\%) aránya, valamint a hyperlipidaemiások aránya is (69\%). A betegek jelentős részének anamnézisében előfordult korábban stroke (9\%) és myocardialis infarctus (MI; 10\%). A betegek 73\%-a jelzett claudicatiós panaszokat. A leggyakoribb gyógyszerek a vérnyomáscsökkentők $(80 \%)$ és a thrombocytagátlók (39\%) voltak.

\section{A BKI alapján negatín, de tünetes csoport}

A leszürt betegek 14\%-a került ebbe a csoportba. Az átlagéletkor 66,3 ( $\pm 7,7$ ) év volt. A leggyakoribb rizikófaktor a hypertonia volt $(82 \%)$, és itt volt a második legmagasabb az aktív dohányzók (27\%) és a korábban dohányzók (22\%) aránya. Ebben a csoportban volt a legmagasabb a korábban szélütésen (14\%) és MI-n (23\%) átesett betegek száma, valamint az ebbe a csoportba tartozó páciensek közül rendelkeztek a legtöbben korábbi LEAD-diagnózissal (34\%). Az összes vizsgált gyógyszercsoport előfordulása ebben a csoportban volt a legnagyobb.

\section{Nem komprimálható artériás csoport}

Ebbe a csoportba a populáció nem elhanyagolható, 12\%-a került. Az átlagéletkor ebben a csoportban volt a legmagasabb: $(66,8( \pm 8,9)$ év. A leggyakoribb rizikófaktor itt is a hypertonia volt $(80 \%)$, és várakozásainknak megfelelöen ebben a csoportban volt a legmagasabb a cukorbetegek aránya $(40 \%)$. Ebben a csoportban volt a legmagasabb az elhízottak aránya is $(80 \%)$.

\section{Különbségek az egyes csoportok között}

Szignifikanciaszinteket számoltunk az egyes csoportok között, ennek eredményeit szintén az 5. táblázat mutatja. A BKI alapján negatív és pozitív csoportok között szignifikáns különbséget találtunk az aktív dohányzók, a hyperlipidaemiások és a korábban szélütésen vagy MI-n átesett páciensek esetében. Fontos kiemelni, hogy a biztosan LEAD-pozitív és a BKI alapján negatív, de tünetes csoport esetében csak a korábbi MI és a claudicatiós pa-
6. táblázat $\mid$ Különbségek az átlagos járástávolságokban az egyes csoportok tünetes betegei között a járásteszt során a biztosan LEAD-pozitív csoporthoz képest

\begin{tabular}{llll}
\hline Járástávolság $(\mathrm{m})$ & $\begin{array}{l}\text { A. Biztosan } \\
\text { LEAD-pozitív } \\
(\mathrm{n}=118)\end{array}$ & $\begin{array}{l}\text { B. BKI-negatív, } \\
\text { de tünetes } \\
(\mathrm{n}=29)\end{array}$ & $\begin{array}{l}\text { C. Nem } \\
\text { komprimálható } \\
\text { artéria }(\mathrm{n}=21)\end{array}$ \\
\hline $\begin{array}{l}\text { Fájdalommen- } \\
\text { tes járástávolság }\end{array}$ & $194,2 \pm 115,6$ & $115,7 \pm 65,1$ & $190,2 \pm 104,3$ \\
$\begin{array}{l}\text { Maximális } \\
\text { járástávolság }\end{array}$ & $271,3 \pm 121,9$ & $168,7 \pm 82,3$ & $246,8 \pm 115$ \\
& p-érték (A vs. B) & p-érték A vs. C & p-érték B vs. C \\
& $<0,001$ & 0,882 & 0,003 \\
& $<0,001$ & 0,393 & 0,007 \\
\hline
\end{tabular}

$\mathrm{BKI}=$ boka-kar index; LEAD = alsó végtagi verőérbetegség

naszokkal rendelkező nők esetében volt szignifikáns különbség.

A járásteszt eredményét az 6. táblázat mutatja. A legkisebb fájdalommentes és maximális járástávolság-átlagot is a BKI-negatív, de tünetes csoportban kaptuk.

\section{Megbeszélés}

A családorvos szerepe a krónikus betegségek és a társuló rizikófaktorok felismerésében kiemelten fontos. A LEAD a gyakori tünetmentessége miatt a családorvosi praxisokban gyakran felismeretlen marad. Emiatt kiemelten fontos az egyszerú, könnyen kivitelezhető, rutinszerúen végezhető szürőeljárások alkalmazásának bevezetése az alapszintű ellátásban.

A jelenlegi ajánlások a noninvazív BKI-mérés elvégzését ajánlják a perifériás verőérbetegség szűrésére. E módszer szenzitivitása és specificitása a LEAD tekintetében $79 \%$ és 96\% közé tehető [15]. A 0,9 vagy az alatti BKIérték már akkor jelezheti az elváltozást, amikor a betegnek még esetleg nincsenek dysbasiás panaszai. Az alacsony BKI-érték továbbá fokozott cardiovascularis rizikót jelent a szimptomatikus és az aszimptomatikus betegek esetén egyaránt, azaz a szív- és érrendszeri halálozás és morbiditás szempontjából egyértelműen prognosztikai jelentőséggel bír [16, 17]. Magyarországon a családorvosi praxisoknak kötelezően rendelkezniük kell folyamatos hullámú, kézi Doppler-UH-készülékkel. A BKI-mérés kivitelezése költséghatékony és gyors, könynyen és nagy biztonsággal reprodukálható, megbízhatósága független a vizsgáló személyétől [18]. Elvégzése betegenként átlagosan 10 percet igényel.

Több, a családorvosok körében külföldön végzett vizsgálat bizonyította, hogy a családorvosok kiemelten fontos vizsgálatnak tartják a BKI-mérést, ám az idő vagy a megfelelő személyzet hiányában sokszor nem kerül elvégzésre [19]. Egy másik vizsgálat szerint, habár a családorvosok szintén fontos diagnosztikus módszernek ítélték, háromnegyedük négynél kevesebb alkalommal 
használta havonta, majdnem felük nem az érvényben lévő szakmai irányelveknek megfelelően, és csak a felük gondolta, hogy a 0,9 alatti BKI-érték a cardiovascularis rizikófaktorok szorosabb kontrollját igényli $[20,21]$. Szűrésünk során tapasztaltuk a más, hasonló vizsgálatokban is fontos felismerést, miszerint a kellő eszközök megléte és a személyzet képzettsége sem garancia a BKI rendszeres kivitelezésére a LEAD fontossága és kockázatai ismeretének hiányában.

Vizsgálatunkban BKI-mérés alapján a bizonyithatóan $L E A D$-csoportba a vizsgált betegek több mint ötöde került, ami egyezik más, hasonló vizsgálatok adataival [1, 7-10, 13]. Ezen csoport átlagéletkora a teljes populáció átlagéletkoránál több mint 2 évvel magasabb volt, ami mutatja az életkornak mint független rizikófaktornak a fontosságát. Habár a szûréseken a nők nagyobb számban jelentek meg, a LEAD-betegek száma a férfiak között másfélszer magasabb volt, ami egyezik az irodalmi adatokkal $[1,4]$.

A LEAD legfontosabb rizikófaktorai megegyeznek a többi atheroscleroticus betegség rizikófaktoraival $[1,6]$. A legfontosabbak a dohányzás, a diabetes mellitus, a hyperlipidaemia és a hypertonia.

A vizsgált populációban a rizikófaktorok nagyszámú előfordulását találtuk, a legtöbb esetben több rizikótényező együttes jelenlétét.

A dohányzás kiemelkedően fontos rizikófaktora a LEAD-nak $[1,4]$. A dohányzás 2-6-szorosára emeli a LEAD előfordulásának rizikóját, ami a dohányzás mértékével és az évek számával együtt emelkedik [22, 23]. Továbbá a dohányzás szorosabb kapcsolatot mutat a LEAD-dal, mint a coronariák megbetegedésével [22]. A vizsgált populáción belül az aktívan dohányzók aránya a biztosan LEAD-pozitín csoportban volt a legmagasabb, másfélszerese a magyarországi átlagnak [24]. Ebben a csoportban volt a korábban dohányzók aránya is a legmagasabb. A dohányzás elhagyása rohamosan csökkenti a claudicatiós panaszok előfordulását [25]. A dohányzás abbahagyására a vizsgálat során a szakorvosi javallat ellenére csak elenyésző számban volt példa $(\mathrm{n}=2)$.

A diabetes mellitus 2-4-szeres kockázatot jelent, emellett ezeknél a betegnél nagyobb a rizikója a kritikus végtagi ischaemia kialakulásának is $[26,27]$. Ezek a betegek ötször nagyobb rizikóval rendelkeznek egy jövőbeli amputációra, és a rizikó a diabeteses évek számával arányosan nő [28]. A vizsgált populáció közel harmada volt cukorbeteg. Ezen betegség előfordulása a nem komprimálható artériás csoportban volt a legmagasabb, várakozásainknak megfelelően, ezt követte a biztosan LEAD-pozitiv és a BKI alapján negatín, de tünetes csoport. Ez az eredmény is mutatja annak jelentőségét, hogy habár a „ködzónába” tartozó betegek diagnosztikai nehézséget jelentenek a családorvos számára, a jelentős rizikófaktorok megléte ezen betegek fokozott utánkövetésére és kontrolljára hívja fel a figyelmet. A cukorbetegek aránya várakozásainknak megfelelően a biztosan LEADnegatí csoportban volt a legalacsonyabb.
A hypertonia az egyik legfontosabb rizikófaktorok egyike, habár kapcsolata a betegséggel gyengébb, mint a coronaria- vagy cerebrovascularis betegségekkel [29, 30]. A betegek több mint háromnegyede volt hypertoniás, és ezzel a magas vérnyomás volt a vizsgált betegek körében a leggyakrabban előforduló rizikófaktor. A hypertonia legmagasabb előfordulását a biztosan LEADpozitív csoportban mértük, a legalacsonyabbat a biztosan LEAD-negatív csoportban, ami még így is igen magas előfordulásnak mondható.

$\mathrm{Az}$ atherosclerosis szoros kapcsolatot mutat a csökkent HDL- és az emelkedett LDL-, valamint trigliceridszinttel [4]. A szürés során a HDL- és LDL-frakció meghatározására nem volt lehetőségünk, és ez nem is képezi a családorvosi rutin-laborvizsgálatok részét. A szakirodalom szerint a teljes koleszterin szintjének jelentős különbsége található a claudicatiós panaszokkal rendelkező és az egészséges betegek között [31], és hasonlóan emelkedett LDL- és csökkent HDL-szintet talált több tanulmány a LEAD-os betegek és a hozzájuk illő kontrollcsoport között [32, 33]. A vizsgált populációban viszonylag magas volt a dyslipidaemiások előfordulása. A legmagasabb arányt a biztosan LEAD-pozitív csoportban kaptuk, és hasonlóan magas előfordulást találtunk a $B K I$-negativ, de tünetes csoportban is.

\section{A ködzóna betegei}

A ködzónába azt a két, speciális figyelmet érdemlő betegcsoportot soroltuk, amelynek tagjai a családorvos számára diagnosztikai nehézséget jelentenek.

A BKI alapján negatín, de tünetes csoport betegei a nyugalmi BKI-mérés alkalmával a normáltartományba estek, az ECQ alapján viszont a claudicatio intermittens tüneteit mutatják jelentősebb megerőltetésre (hegymenet, lépcsőzés). Ezekben az esetekben kiemelten fontos a részletes anamnézisfelvétel, hogy ezt a járáskor jelentkező fájdalmat el tudjuk különíteni az idegi, illetve ízületi betegségek talaján kialakuló fájdalomtól, illetve a vénás panaszoktól. Azon betegek esetében, akiknél a nyugalmi BKI-mérés normális értéket ad, de a beteg panaszokkal rendelkezik az ECQ alapján, szükséges további terheléses vizsgálat elvégzése (általában 'treadmill' [járópadló-] teszt Strandness-protokoll szerint $[3 \mathrm{~km} / \mathrm{h}, 10 \%$-os hegymenet]) és a betegek további szakorvosi vizsgálata. Amennyiben a 'treadmill' teszt végén (a maximális járástávolság elérésekor) a bokánál mért szisztolés érték >30 Hgmm-rel csökken, vagy a terhelést követő BKI-csökkenés $>20 \%$, a LEAD diagnózisa felállítható [1]. A vizsgált populáció több mint tizede került ide, és a csoport rizikófaktor-profilja közeli hasonlóságot mutatott a biztosan LEAD-pozití csoport betegeiével, ami ezen betegek korai felismerésére hívja fel a figyelmet. Köztük találtuk a második legtöbb aktív dohányzót a biztosan LEAD-pozitív csoport betegei után, és itt volt a második legmagasabb a hypertonia és a hyperlipidaemia előfordulása is. Ebben a csoportban találtuk a legmagasabb előfordulá- 


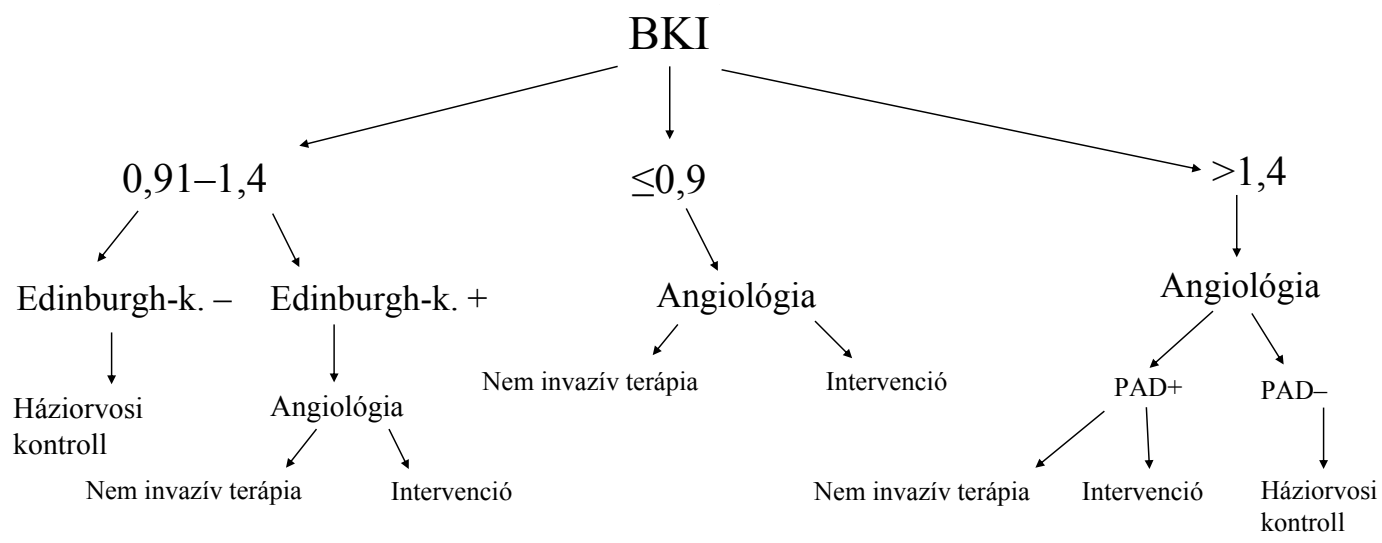

2. ábra

$$
\mid \begin{aligned}
& \text { Folyamatábra a családorvos lehetőségeiről } \\
& \mathrm{BKI}=\text { boka-kar index; } \mathrm{k} . \text { = kérdőív; PAD = perifériás artériás érbetegség }
\end{aligned}
$$

sát korábbi stroke-nak vagy szívinfarktusnak. Szignifikáns különbséget a két csoport között egyedül a korábbi MI előfordulásában találtunk. Ezek az eredmények is mutatják annak fontosságát, hogy nem hagyatkozhatunk csupán a nyugalmi BKI-értékre a LEAD diagnózisánál, mindenképp ajánlott a többirányú megközelítés.

A másik, különösebb figyelmet érdemlő csoport a nem komprimálható artériával rendelkező betegek csoportja. Ebbe a csoportba kerültek azok a betegek, akiknek valamilyen okból összenyomhatatlanok az artériáik, így hamisan magas, 1,4 feletti nyomásértékeket kaptunk. Ez többnyire a diabetes mellitus talaján kialakuló Mönckeberg-féle mediasclerosis miatt van, de magyarázhatja az előrehaladottabb életkorban gyakrabban előforduló általános atherosclerosis is, illetve genetikai faktorok vagy krónikus vesebetegség [7]. A vizsgált populáció több mint tizede került ebbe a csoportba. Jellemzően ebben a csoportban találtuk a diabetes mellitus és az elhízás legnagyobb előfordulását, társulva a legmagasabb életkori átlaggal. A családorvos kompetenciája ebben az esetben is a veszélyeztetett betegek kiszürése és megfelelő szakrendelésre való továbbítása. Ebben az esetben fontos eldönteni, hogy ez a meszesedés a lument szúkíti-e vagy sem. Fontos segítség lehet az Edinburgh-kérdőív és a járásteszt annak eldöntésére, hogy a páciensnek vannak-e dysbasiás panaszai. Az irányelvek ebben az esetben az öregujj-kar index (TBI) elvégzését javasolják [1, 7], amelyet több módszer segítségével, angiológiai szakellátóhelyen lehet kivitelezni. Ha az ezzel a módszerrel mért érték 0,7 alatt van, kimondható a LEAD diagnózisa.

A 2. ábrán összefoglaltuk, hogy a családorvos milyen séma szerint szürheti ki, illetve továbbíthatja a veszélyeztetett betegeket a megfelelő szakorvosokhoz.

\section{Következtések}

A családorvos szerepe különösen fontos a LEAD korai felismerésében. Az általunk kipróbált szűrőmódszer képes volt a nagyobb vizsgálatok adatait produkálni, olcsó, a családorvos eszközeivel könnyen kivitelezhető, kevés időt vesz igénybe, és nagyobb populáción is megbízhatóan alkalmazható. A módszer komplexitása olyan veszélyeztetett betegcsoportok felismerését is lehetővé teszi, amelyek az egyszerú eszközös vizsgálat révén az orvos szeme elől rejtve maradhatnak, illetve differenciáldiagnosztikai szempontból további vizsgálatra szorulnak. Különösen fontos ez Magyarország olyan területein, ahol a térség szerényebb anyagi körülményei és a roszszabb egészségügyi hozzáférhetőség miatt a veszélyeztetett betegek ritkán kerülnek felismerése és szakorvosi kezelésre. A komplex szürés családorvosi szintű megkezdésével ezen betegek könnyebben felismerhetők lesznek, kezelésük időben megkezdhető, hosszú távon jelentősen javítva e páciensek életminőségét és életkilátásait, valamint csökkentve az egészségügyi ellátás terheit.

Anyagi támogatás: A közlemény megírása anyagi támogatásban nem részesült.

Szerzôi munkamegosztás: T.-V. Zs.: Hipotézis, a vizsgálat lefolytatása, a cikk szövegezése és az ábrák elkészítése. T.-V. G.: Hipotézis, a cikk szövegezése. G. Zs.: A vizsgálat lefolytatása. Sz. B.: Statisztika. J. Z.: Hipotézis, a cikk szövegezése. A cikk szövegezése. S. P.: Hipotézis, a cikk szövegezése. A cikk végleges változatát mindegyik szerző olvasta és jóváhagyta.

Érdekeltségek: A szerzőknek nincsenek érdekeltségeik.

\section{Irodalom}

[1] Aboyans V, Ricco J, Bartelink M, et al. The ESC Guidelines on the diagnosis and treatment of peripheral artery diseases. Eur Heart J. 2018; 39: 763-816.

[2] Kolossváry E, Ferenci T, Kováts T, et al. Trends in major lower limb amputation related to peripheral arterial disease in Hungary: a nationwide study (2004-2012). Eur J Vasc Endovasc Surg. $2015 ; 50: 78-85$.

[3] Institute for Health Metrics and Evaluation. Seattle, WA. Available from: https://vizhub.healthdata.org/gbd-compare/ [accessed: March 18, 2020]. 
[4] Criqui MH, Denenberg JO, Langer RD, et al. The epidemiology of peripheral arterial disease: importance of identifying the population at risk. Vasc Med. 1997; 2: 221-226.

[5] Ness J, Aronow WS. Prevalence of coexistence of coronary artery disease, ischemic stroke, and peripheral arterial disease in older persons, mean age 80 years, in an academic hospital-based geriatrics practice. J Am Geriatr Soc. 1999; 47: 1255-1256.

[6] Stoffers HE, Rinkens PE, Kester AD, et al. The prevalence of asymptomatic and unrecognized peripheral arterial occlusive disease. Int J Epidemiol. 1996; 25: 282-290.

[7] Tendera M, Aboyans V, Bartelink MR, et al. ESC Guidelines on the diagnosis and treatment of peripheral artery diseases. Document covering atherosclerotic disease of extracranial carotid and vertebral, mesenteric, renal, upper and lower extremity arteries. The Task Force on the Diagnosis and Treatment of Peripheral Artery Diseases of the European Society of Cardiology (ESC). Eur Heart J. 2011; 32: 2851-2906.

[8] Criqui MH, Fronek A, Barrett-Connor E, et al. The prevalence of peripheral arterial disease in a defined population. Circulation 1985; 71: 510-515.

[9] Criqui MH. Peripheral arterial disease - epidemiological aspects. Vasc Med. 2001; 6(3 Suppl): 3-7.

[10] Schroll M, Munck O. Estimation of peripheral arteriosclerotic disease by ankle blood pressure measurements in a population study of 60-year-old men and women. J Chronic Dis. 1981; 34: 261-269.

[11] Hiatt WR, Marshall JA, Baxter J, et al. Diagnostic methods for peripheral arterial disease in the San Luis Valley Diabetes Study. J Clin Epidemiol. 1990; 43: 597-606.

[12] Selvin E, Erlinger TP. Prevalence of and risk factors for peripheral arterial disease in the United States: results from the National Health and Nutrition Examination Survey 1999-2000. Circulation 2004; 110: 738-743.

[13] Farkas K, Járai Z, Kolossváry E, et al. High prevalence of peripheral arterial disease in hypertensive patients: the evaluation of ankle-brachial index in Hungarian hypertensives screening program, for the ERV Study Group. J Hypertens. 2012; 30: 15261532 .

[14] Leng GC, Fowkes FG. The Edinburgh Claudication Questionnaire: an improved version of the WHO/Rose Questionnaire for use in epidemiological surveys. J Clin Epidemiol. 1992; 45: 1101-1109.

[15] Lijmer JG, Hunink MG, van den Dungen, et al. ROC analysis of noninvasive tests for peripheral arterial disease. Ultrasound Med Biol. 1996; 22: 391-398.

[16] Diehm C, Lange S, Darius P, et al. Association of low ankle brachial index with high mortality in primary care. Eur Heart $\mathrm{J}$. 2006; 27: 1743-1749.

[17] Wild SH, Byrne CD, Smith FB, et al. Low ankle-brachial pressure index predicts increased risk of cardiovascular disease independent of the metabolic syndrome and conventional cardiovascular risk factors in the Edinburgh Artery Study. Diabetes Care 2006; 29: 637-642.

[18] Holland-Letz T, Endres HG, Biedermann S, et al. Reproducibility and reliability of the ankle-brachial index as assessed by vascular experts, family physicians and nurses. Vasc Med. 2007; 12: $105-112$.
[19] Yap Kannan R, Dattani N, Sayers RD, et al. Survey of anklebrachial pressure index use and its perceived barriers by general practitioners in the UK. Postgrad Med J. 2016; 92: 322-327.

[20] Davies JH, Kenkre J, Williams EM. Current utility of the anklebrachial index $(\mathrm{ABI})$ in general practice: implications for its use in cardiovascular disease screening. BMC Fam Pract. 2014; 15: 69.

[21] Haigh KJ, Bingley J, Golledge J, et al. Barriers to screening and diagnosis of peripheral artery disease by general practitioners. Vasc Med. 2013; 18: 325-330.

[22] Fokwes FG, Rudan D, Rudan I, et al. Comparison of global estimates of prevalence and risk factors for peripheral artery disease in 2000 and 2010: a systematic review and analysis. Lancet 2013; 382: 1329-1340.

[23] Price JF, Mowbray PI, Lee AJ, et al. Relationship between smoking and cardiovascular risk factors in the development of peripheral arterial disease and coronary artery disease: Edinburgh Artery Study. Eur Heart J. 1999; 20: 344-353.

[24] Tombor I, Paksi B, Urbán R, et al. Prevalence of smoking among the Hungarian adult population. [A dohányzás elterjedtsége a magyar felnőtt lakosság körében.] Népegészségügy 1988; 88: 149-154. [Hungarian]

[25] Kannel WB, Shurtleff D. The Framingham Study: cigarettes and the development of intermittent claudication. Geriatrics 1973; 28: 61-68.

[26] Beks PJ, Mackaay AJ, de Neeling JN, et al. Peripheral arterial disease in relation to glycaemic level in an elderly Caucasian population: the Hoorn study. Diabetologia 1995; 38: 86-96.

[27] Jude EB, Oyibo SO, Chalmers N, et al. Peripheral arterial disease in diabetic and nondiabetic patients: a comparison of severity and outcome. Diabetes Care 2001; 24: 1433-1437.

[28] Murabito JM, D'Agostino RB, Silbershatz H, et al. Intermittent claudication. A risk profile from The Framingham Heart Study. Circulation 1997; 96: 44-49.

[29] Novo S, Avellone G, Di Garbo V, et al. Prevalence of risk factors in patients with peripheral arterial disease: a clinical and epidemiological evaluation. Int Angiol. 1992; 11: 218- 229.

[30] Bainton D, Sweetnam P, Baker I, et al. Peripheral vascular disease: consequence for survival and association with risk factors in the Speedwell prospective heart disease study. Br Heart J. 1994; 72: $128-132$.

[31] Sanderson KJ, van Rij AM, Wade CR, et al. Lipid peroxidation of circulating low density lipoproteins with age, smoking and in peripheral vascular disease. Atherosclerosis 1995; 118: 45-51. [Correction: Atherosclerosis 1996; 121: 295.]

[32] Hørby J, Grande P, Vestergaard A, et al. High density lipoprotein cholesterol and arteriography in intermittent claudication. Eur J Vasc Surg. 1989; 3: 333-337.

[33] Bradby GV, Valente AJ, Walton KW. Serum high-density lipoproteins in peripheral vascular disease. Lancet 1978; 2(8103): 1271-1274.
(Tóth-Vajna Zsombor dr., Budapest, Szarvas tér 1., 1013 e-mail: tothzsomi@gmail.com)

A cikk a Creative Commons Attribution 4.0 International License (https://creativecommons.org/licenses/by/4.0/) feltételei szerint publikált Open Access közlemény, melynek szellemében a cikk bármilyen médiumban szabadon felhasználható, megosztható és újraközölhetö, feltéve, hogy az eredeti szerző és a közlés helye, illetve a CC License linkje és az esetlegesen végrehajtott módosítások feltüntetésre kerülnek. (SID_1) 